PRACTICAL RAILWAY ENGINEERING 
This page is intentionally left blank 


\title{
PRACTICAL RAILWAY ENGINEERING
}

\author{
Clifford F Bonnett \\ C. Eng., F. I. C. E., F. I. Struct. E.
}




\author{
Published by \\ Imperial College Press \\ 516 Sherfield Building \\ Imperial College \\ London SW7 2AZ
}

\title{
Distributed by
}

World Scientific Publishing Co. Pte. Ltd.

P O Box 128, Farrer Road, Singapore 912805

USA office: Suite 1B, 1060 Main Street, River Edge, NJ 07661

UK office: 57 Shelton Street, Covent Garden, London WC2H 9HE

\section{British Library Cataloguing-in-Publication Data}

A catalogue record for this book is available from the British Library.

\section{PRACTICAL RAILWAY ENGINEERING}

Copyright $\odot 1996$ by Imperial College Press

All rights reserved. This book, or parts thereof, may not be reproduced in any form or by any means, electronic or mechanical, including photocopying, recording or any information storage and retrieval system now known or to be invented, without written permission from the Publisher.

\footnotetext{
For photocopying of material in this volume, please pay a copying fee through the Copyright Clearance Center, Inc., 222 Rosewood Drive, Danvers, MA 01923, USA. In this case permission to photocopy is not required from the publisher.
}

ISBN $\quad 1-86094-012-9$

Printed in Singapore. 
This book is dedicated to my wife

\section{JEAN}

without whose support and encouragement this book could not have been written. 
This page is intentionally left blank 


\section{Foreword}

As we approach a new millenium, transport of people and materials takes on an even greater significance world-wide than it has in the immediate past. The birth and evolution of railways during the last two centuries has had an immeasurable influence on industrial, social and economic development.

Engineers of all backgrounds and professional disciplines have played a leading role in the development, operation and management of railways. In future the contribution of railway engineers should be even more significant.

I am delighted to be able to write this foreword to Cliff Bonnett's book. I have known him now for seventeen years. His wide experience 'on the ground' with British Rail, London Underground and Docklands Light Railway, over almost thirty five years, ensures that this textbook has a sure foundation.

Recent years lecturing on a part-time basis at Imperial College have also shown that Cliff is well able to communicate in a simple and concise manner. I commend this book to all who wish to get a good overview of Railway Engineering.

Tony M Ridley, CBE, PhD, FEng, FICE, FCIT, Professor of Transport Engineering Centre for Transport Studies Imperial College of Science Technology \& Medicine University of London 
This page is intentionally left blank 


\section{Preface}

The need for this textbook arose out of the author's experience whilst co-ordinating the optional subject 'Railway Engineering Concepts' for the Intercollegiate MSc Course in Transport run jointly by Imperial College and University College, London University.

The stated objective of this optional subject is;

'To develop an understanding of the engineering concepts involved, for all disciplines, in the planning, design, construction, equipping, maintenance and renewal of all types of railway.'

The author quickly discovered that there are many textbooks which give detailed information on various aspects of railway engineering, usually confined to one or two main disciplines, but none that give a general 'broad brush' approach to the subject as a whole.

This textbook is designed to fill this gap, not only for the student on this or similar courses but to be a useful reference book to all who need to expand their knowledge in this field to cover a wide spectrum.

The author wishes to acknowledge extensive help he has received from many practicing engineers and in particular those who regularly have contributed lectures on this subject to students on the London University course. 
This page is intentionally left blank 


\title{
Acknowledgements
}

The author wishes to express his thanks to the Professors, lecturers and staff of the Centre for Transport Studies of the University of London for the practical help given in the production of this textbook.

In particular, he would also wish to record thanks to the following external lecturers who have assisted with material outside his own railway practical experience:

\author{
Eddie Goddard \\ Chris Hardie \\ Dr. Bob Holmes \\ Chris Holmes \\ Dr. John Medhurst \\ Terry Mahoney \\ John Vint
}

Appreciation is also expressed to British Rail, London Underground Ltd, Docklands Light Railway Ltd, The Science Museum, the Institution of Railway Signal Engineers and the Permanent Way Institution for assistance with the gathering of facts, information and illustrations.

I am particularly grateful to Professor Tony Ridley who has been a great encourager and has written the Foreword during his very busy year as President of the Institution of Civil Engineers. 
This page is intentionally left blank 


\section{Contents}

Foreword vii

Preface ix

Acknowledgements $\quad x i$

1. Introduction 1

1.1 Early beginnings 1

1.2 Development and diversification $\quad 2$

1.3 The customer 3

1.4 The operator 3

1.5 Overall planning $\quad 4$

1.6 Choice of route and level 5

1.7 Resources required 5

2. Station Layout 9

2.1 The customer and the design process 9

$\begin{array}{ll}2.2 \text { The need for standards } & 10\end{array}$

$\begin{array}{ll}2.3 \text { Objectives of station planning } & 11\end{array}$

2.4 Concept of speed and flow 12

$\begin{array}{ll}2.5 \text { Consideration of time } & 13\end{array}$

$\begin{array}{ll}2.6 \text { Planning normal operation } & 14\end{array}$

$\begin{array}{ll}2.7 \text { Demand Matrix } & 15\end{array}$

$\begin{array}{ll}2.8 \text { Capacity requirements } & 17\end{array}$

$\begin{array}{ll}2.9 \text { Ticket halls } & 18\end{array}$

2.10 Access and interchange $\quad 21$ 
2.11 Stairs, escalators and lifts $\quad 22$

$\begin{array}{ll}2.12 \text { Platforms } & 23\end{array}$

2.13 Footbridges and subways 24

2.14 Station canopies $\quad 25$

2.15 Access for the disabled 25

2.16 The 'Downgraded' station 26

2.17 Planning for hazards $\quad 27$

$\begin{array}{ll}2.18 \text { Staff accommodation } & 28\end{array}$

$\begin{array}{ll}2.19 & \text { Designing for maintenance } \\ \end{array}$

3. Rolling Stock 31

3.1 Definition of railway rolling stock 31

3.2 Range of rolling stock 33

3.3 Evolution of steam 34

3.4 Advent of electric traction $\quad 37$

3.5 Development of electric traction $\quad 39$

3.6 Diesel traction 41

3.7 Evolution of wheel layout $\quad 42$

3.8 Changes in locomotive maintenance 43

3.9 Carriages to modern carbodies 43

$\begin{array}{ll}3.10 \text { Carbody structures } & 46\end{array}$

3.11 Train performance on main line 47

3.12 Train performance on metros/light rail 47

3.13 Freight rolling stock $\quad 49$

3.14 Engineering rolling stock $\quad 50$

3.15 Manufacturing methods $\quad 52$

4. Depots and Workshops 53

4.1 Proper maintenance of rolling stock 53

4.2 Maintenance considerations $\quad 54$

4.3 Establishing a maintenance regime $\quad 54$

4.4 Maintenance management 55

4.5 Balance between workshops and depots 56

4.6 Depot siting $\quad 57$

4.7 Needs of the Maintainer 59

4.8 Basic requirements for depots 60 
4.9 Performance indicators and audit 62

5. Track 63

5.1 Origin and development of railway track 63

5.2 Basic components $\quad 65$

5.3 Track ballast 65

5.4 Materials for track ballast 66

$\begin{array}{ll}5.5 \text { Sleeper functions } & 67\end{array}$

5.6 Timber sleepers $\quad 67$

5.7 Concrete sleepers (monobloc) 69

5.8 Twin block concrete sleepers 71

5.9 Steel sleepers $\quad 71$

5.10 Rail fastenings $\quad 72$

$\begin{array}{lll}5.11 \text { Rails } & 74\end{array}$

$\begin{array}{ll}5.12 \text { Rail wear } & 76\end{array}$

$\begin{array}{ll}5.13 \text { Desirability of removing rail joints } & 77\end{array}$

$\begin{array}{ll}5.14 & \text { Introduction of track welding }\end{array}$

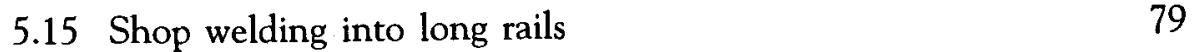

$\begin{array}{ll}5.16 \text { Site welding into CWR } & 79\end{array}$

$\begin{array}{ll}5.17 \text { Rail stressing } & 81\end{array}$

5.18 Points, switches and crossings $\quad 81$

5.19 Crossing design and manufacture $\quad 82$

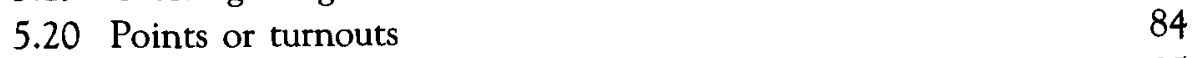

5.21 Driving, locking and detection 85

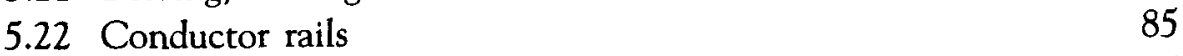

5.23 Paved concrete track $\quad 86$

5.24 Cast-in sleeper track $\quad 87$

5.25 Floating slab track $\quad 87$

5.26 Track installation and renewal $\quad 87$

5.27 Day-to-day maintenance $\quad 88$

6. Earthworks, Drainage and Fencing 91

6.1 Stability of earthworks 91

6.2 Short term considerations 92

6.3 Long term considerations 92

6.4 Slips 93 
6.5 Detection of movement

6.6 Dealing with embankment slips 95

$\begin{array}{ll}\text { 6.7 Dealing with cutting slips } & 97\end{array}$

6.8 Drainage of the track bed 98

6.9 Sand blankets

99

6.10 Side or cess drains

100

6.11 Centre drains

100

6.12 Drain cleaning

101

6.13 Ineffective drains

102

6.14 Railway fencing

$\begin{array}{ll}\text { 7. Bridges and Structures } & 105\end{array}$

$\begin{array}{ll}7.1 \text { Early railway structures and materials } & 105\end{array}$

$\begin{array}{ll}7.2 \text { Modern welded steelwork } & 108\end{array}$

$\begin{array}{ll}7.3 \text { Reinforced concrete structures } & 111\end{array}$

7.4 Prestressed concrete 113

$\begin{array}{ll}7.5 \text { Bridge reconstruction } & 116\end{array}$

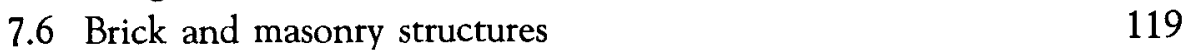

$\begin{array}{ll}7.7 \text { Examination of structures } & 120\end{array}$

$\begin{array}{lll}7.8 \text { Structural maintenance } & 122\end{array}$

7.9 Strength assessment 122

8. Tunnels and Tunnelling 125

8.1 History of tunnelling $\quad 125$

8.2 Cut-and-cover tunnels 126

$\begin{array}{lll}8.3 \text { First tunnel shields } & 127\end{array}$

$\begin{array}{ll}8.4 \text { Modern tunnel shields } & 128\end{array}$

$\begin{array}{ll}\text { 8.5 Differing ground conditions } & 129\end{array}$

$\begin{array}{ll}8.6 \text { Construction methods } & 129\end{array}$

8.7 Tunnel linings 130

8.8 Vertical and sloping shafts 132

8.9 Tunnel inspection and maintenance 133

9. Electrification 135

9.1 Electricity as a form of motive power 135

$\begin{array}{ll}9.2 \text { Generation of electricity } & 136\end{array}$ 
$\begin{array}{ll}\text { 9.3 Railway electrification systems } & 136\end{array}$

9.4 The AC system connection of supply 138

9.5 AC feeder points 138

$\begin{array}{ll}9.6 \mathrm{AC} \text { overhead equipment } & 139\end{array}$

9.7 Earthing on the AC system 140

$\begin{array}{ll}9.8 \text { Electrical interference } & 141\end{array}$

9.9 DC low voltage systems 141

9.10 AC power distribution for DC systems 142

9.11 DC power distribution 143

9.12 Effects of electrification 144

9.13 Inspection and maintenance 145

10. Signalling and Train Control 147

10.1 Early history of signalling $\quad 147$

10.2 Modern signalling $\quad 149$

10.3 Track circuits 150

10.4 Point operation, locking and detection 151

10.5 Interlocking $\quad 152$

10.6 Minimum headways 153

10.7 Home and distant signals $\quad 154$

10.8 Subsidiary signals $\quad 154$

10.9 Two aspect colour light signalling $\quad 155$

10.10 Three aspect colour light signalling 156

10.11 Four aspect colour light signalling $\quad 157$

10.12 Transmission based signalling 159

10.13 Proof of safety and safety standards 160

11. Systems and Communications 163

11.1 Getting things done! 163

$\begin{array}{ll}11.2 \text { Human processes } & 164\end{array}$

$\begin{array}{ll}11.3 \text { Good feedback } & 164\end{array}$

11.4 Interface between operation and engineering 166

11.5 Interface between operation and the user 166

$\begin{array}{ll}11.6 \text { Railway systems pyramid } & 167\end{array}$

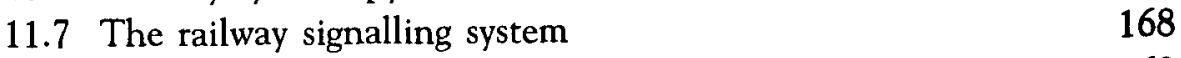

$\begin{array}{ll}11.8 \text { The public address system } & 169\end{array}$ 
11.9 Telephones and radio

11.10 Closed circuit TV

11.11 Equipment operation and maintenance

12. Lifts, Escalators and Pumps

12.1 Vertical transportation

12.2 Development of early lifts

12.3 Development of escalators

12.4 Passenger flows to and from escalators and/or lifts

12.5 Achievable flow rates for modern lifts

12.6 Flow rates on escalators

12.7 Types of escalators

12.8 Compact type escalator

12.9 Semi-compact type escalators

12.10 Heavy duty public service escalators

12.11 Typical HDPS escalator dimensions

184

12.12 Types of modern lift

184

12.13 Application of lift types

185

12.14 Safety risks and human factors

185

12.15 Inspection and maintenance

12.16 Pumps

\section{Ventilation and Draught Relief}

13.1 Is ventilation a problem on railways?

13.2 Movement of air

13.3 Deciding on exhaust or pressure

13.4 The 'piston' effect

13.5 Design and operation of tunnel fans

13.6 Smoke in tunnels

13.7 Draught relief

13.8 Maintenance and inspection of fans

14. Future Trends

14.1 Engineering 'full circle'

14.2 The trend towards broader vision

14.3 The trend towards local accountability 
14.4 Increasing Information Technology

14.5 Improved interchange between transport modes

14.6 A move towards design for Maintenance

202

14.7 Trends in comfort standards

202

15. Conclusion

203

15.1 Retrospect

203

15.2 Postscript

204

Subject Index 


\section{List of Illustrations}

Fig. 1.1 Early railway construction

Fig. 1.2 Underground railway construction at Blackfriars 4

Fig. 1.3 Concourse and roof at Paddington 6

Fig. 2.1 Typical country station 11

Fig. 2.2 Typical sub-surface booking hall 12

Fig. 2.3 Matrix of passenger flows 15

Fig. 2.4 Congestion at foot of escalator 16

Fig. 2.5 Pedestrian flow during crowding 16

Fig. 2.6 Different categories of passengers on a concourse 20

Fig. 2.7 Passenger movements during 'Dwell time' 23

Fig. 2.8 Lift for the disabled, Docklands Light Railway 26

Fig. 3.1 Early flanged wheels and rails 32

Fig. 3.2 'The Age of Steam' 33

Fig. 3.3 Euston Square station showing ventilation openings 36

Fig. 3.4 An early Underground DC electric locomotive 37

Fig. 3.5 Modern multiple unit tube train 38

Fig. 3.6 Southern Region(BR) multiple unit DC stock 39

Fig. 3.7 Channel Tunnel stock which can run on either

DC third rail or AC overhead current collection $\quad 40$

Fig. 3.8 Modern diesel-electric locomotive 41

Fig. 3.9 Typical 'slam door' compartment stock 44

Fig. 3.10 Modern open plan passenger coach 45

Fig. 3.11 Docklands Light Railway stock 45

Fig. 3.12 Specialist freight wagons $\quad 49$

Fig. 3.13 Ballast tamping machine $\quad 50$ 
Fig. 4.1 Diesel-electric depot/workshop $\quad 57$

Fig. 4.2 Typical Metro depot for LUL 58

Fig. 4.3 DLR depot during construction $\quad 59$

Fig. 4.4 Train Washing Machine 61

Fig. 5.1 Bullhead section rail $\quad 64$

Fig. 5.2 Recommended ballast depths 66

Fig. 5.3 Individual renewal of timber sleepers on LUL 68

Fig. 5.4 Standard Prestressed Concrete Sleepers 70

Fig. 5.5 Flat Bottom Rail 72

Fig. 5.6 The Pandrol Clip 74

Fig. 5.7 Continuous Welded Track $\quad 80$

Fig. 5.8 A crossover layout in $\mathrm{BH}$ rail $\quad 82$

Fig. 5.9 Components of Points/Turnouts 84

Fig. 5.10 Modern main line track installation $\quad 88$

Fig. 5.11 Day time Track Maintenance Gang at work $\quad 89$

Fig. 6.1 Well maintained Embankment Slope 93

Fig. 6.2 Counterforts and Herring-bone Drainage 97

Fig. 6.3 A Sump Clearing Pump Train 101

$\begin{array}{ll}\text { Fig. 6.4 Drainage catchpit } & 103\end{array}$

Fig. 6.5 Fence for Third/Fourth Rail Electrified Railway 103

Fig. 7.1 Laminated timber arched bridge at Lancaster 106

Fig. 7.2 Hundred year old cast iron arches at Kilburn 107

Fig. 7.3 Reconstructed girder bridge at Kilburn 109

Fig. 7.4 Welded truss railway bridge 110

Fig. 7.5 Welded tubular station roof at Waterloo 110

Fig. 7.6 Reinforced concrete station portal frame (1930's) 111

Fig. 7.7 Railway bridge reconstructed using pretensioned prestressed concrete beams $\quad 114$

Fig. 7.8 Concrete segmental box units $\quad 115$

Fig. 7.9 Erection of new girders, Lune Viaduct 117

Fig. 7.10 100 Ton Rolling-in trolley 118

Fig. 7.11 Brick arched underbridge still giving service $\begin{array}{ll}\text { after } 150 \text { years } & 120\end{array}$

Fig. 8.1 Early Cut-and-cover construction in London 126

$\begin{array}{ll}\text { Fig. 8.2 Modern soft ground tunnel shield } & 128\end{array}$ 
Fig. 8.3 Expanded concrete linings

Fig. 8.4 Concrete lined vertical shaft

Fig. 9.1 Diagram of typical $25 \mathrm{kV}$ Feeding Arrangement

Fig. 9.2 Modern $25 \mathrm{kV}$ Overhead Equipment

Fig. 9.3 AC and DC distribution on a DC system

Fig. 10.1 Semaphore Signals

Fig. 10.2 The DC Track Circuit

Fig. 10.3 Diagram showing point locking and detection

Fig. 10.4 Headway distance and time

Fig. 10.5 Two Aspect signalling

Fig. 10.6 Three Aspect signalling

Fig. 10.7 Four Aspect signalling

158

Fig. 11.1 Open and closed loop systems 165

Fig. 11.2 The systems pyramid 167

Fig. 12.1 An early Underground escalator 177

Fig. 12.2 A modern railway design using escalators and lift 179

Fig. 12.3 Typical semi-compact escalator

Fig. 12.4 Heavy duty public service escalator 